\title{
STUDY OF CUSTOMER SATISFACTION WITH LIVING CONDITIONS IN NEW APARTMENT BUILDINGS
}

\author{
Natalija Lepkova \\ Vilnius Gediminas Technical University, Vilnius, Lithuania \\ e-mail:natalija.lepkova@vgtu.lt
}

Egle Butkiene

Financial group manager, JSC Cognizant Technology Solutions, Lithuania

e-mail: eglekacinskaite@gmail.com

\section{Miroslaw Bełej}

University of Warmia and Mazury in Olsztyn, Poland

e-mail:miroslaw.belej@uwm.edu.pl

\begin{abstract}
The article aims to analyze the Lithuanian housing market and to look into the satisfaction of people with living conditions in new apartment buildings on this market. The article presents the concept of customer satisfaction in construction and the criteria that define the quality of dwellings; the benefits, consequences, merits and demerits of the assessment of customer satisfaction are also named. A survey of customer satisfaction helped to evaluate the quality of dwellings according to their technical and functional parameters, as well as the degree of cooperation between customers and contractors/builders. The customer satisfaction index (CSI) and the degree of loyalty were calculated, and then a customer satisfaction matrix was built up.
\end{abstract}

Key words: customer satisfaction index, construction quality, real estate market.

JEL Classification: A10, R29, R30.

Citation: Lepkova N., Butkiene E. Bełej M., 2016, Study of Customer Satisfaction with Living Conditions in New Apartment Buildings, Real Estate Management and Valuation, Vol. 24, No. 3, pp. 52-70.

DOI: 10.1515/remav-2016-0021

\section{Introduction}

One can hardly envisage national economic and social development without the construction industry, while the main product of construction-housing-is inevitably important to people, contributes to the quality of their lives and satisfies social as well as other needs.

In contrast to the prices of other products, those of real estate depend not only on the supply, demand and competition in the market, but also on the quality of construction products and services, negotiation skills of buyers and sellers, and satisfaction of the parties (URBANAVIČIENĖ et al. 2009). Constant and good communication with customers is a source of both advantages and threats; mutual trust and cooperation between the parties is, therefore, paramount. Appropriate management of all processes is necessary in order to ensure good relationships with customers during construction projects (PEKKANEN 2005).

Recently, there has been an emerging necessity to improve the degree of customer satisfaction and quality in construction. Construction companies started emphasizing the importance of customer satisfaction. Traditional measuring techniques, such as regulated product quality, are too simple to assess the environment and the result of a construction project. The concept of customer satisfaction 
states that a project can be successful only when it satisfies the needs of current and future customers, the main needs being quality, time and cost effectiveness.

The management of customer satisfaction in construction is not straightforward and direct, mostly because the construction industry is very distinct: temporary, unique, specific and exclusive (KÄRNÄ et al. 2009). This industry differs from others in the eyes of customers because each construction project is usually exclusive; hence, similar examples are harder to come by and referring to a previous survey of customer satisfaction in the future is not easy either (KÄRNÄ et al. 2004). The quality of construction products and services, as well as the success of the entire project, depend on the parties involved in the process-such as the customers, the architect, the builder, on fulfilled expectations, and on ongoing quality improvement. Better work performed by principals, contractors and subcontractors is maintained as the reason behind improved customer satisfaction and better reputation, which, in turn, ensures competitiveness in the market (SOETANTO et al. 2001). An organization must regularly assess customer satisfaction to find out the level of satisfaction among its customers. The level of customer satisfaction in construction becomes clear only in the final phases of a construction project (DAUNORIENĖ et al. 2006).

\section{Customer satisfaction and behavior in construction}

\subsection{The concept of customer satisfaction}

A customer is defined as a person who pays for a product or service and generally dictates the requirements (KUJALA 2002). The end user in construction can be a buyer of products and services. Customers in construction differ from those in other industries, their main shortcoming being the lack of experience. During construction, customers lack the proper conditions, experience and skills to assess the physical quality of structures and are, therefore, forced to assess only the quality of the provided services and the final product. Even then, however, the customer focuses on the assessment of functional rather than technical parameters (FORSYTHE 2008).

Customer satisfaction is a function of perceivable quality and unfulfilled expectations; it illustrates the scope of discrepancies between the quality and expectations. The customer compares the expected product or service to certain specifications and standards. He or she is satisfied when the expected specifications exceed the standards, while those found to be below the standards lead to discontent (KÄRNÄ 2004). Hence, the customer's satisfaction may be defined as personal satisfaction or disappointment caused by differences between the received product or service and the customer's expectations (KOSKELA 2002). Customer satisfaction may also be defined as a state in which every need, wish and expectation of a customer is met or exceeded throughout the product or service lifecycle, leading to another purchase, loyalty, and favorable references. It is determined by the following main factors: the key components of a product or service, the key services provided, the reimbursement process to neutralize bad experiences, and special services (KOSKELA 2002).

A customer's satisfaction with a product or service is mostly determined by initial customer expectations based on experience, received tips, and the information given as well as promises made by sellers and competitors (KOTLER 2003). In the case of customers' satisfaction, their expectations are met. In case of customers' gratification, their expectations are exceeded. Customer gratification, therefore, means that a customer obtained a product with unexpected characteristics. Hence, a manufacturer, supplier or seller must foresee which features of their product would give their customers unexpected pleasure or gratify them (DIKAVIČIUS et al. 2003). A delighted customer raises the quality standards a step higher, making it more difficult to satisfy them in the future; companies seeking to delight their customers therefore face risks. On the other hand, such a customer benefits the company by giving a considerable competitive edge against other companies which are unable to offer similar products or services. Though customer satisfaction is a rather new phenomenon in construction, it is increasingly becoming the main goal of companies in their quest to improve the quality of their products and services, and to maintain competitiveness in the market (KäRNÄ 2004).

Construction companies implement total quality management methods to improve their performance; the construction industry, however, is lagging behind other industries because of its failure to precisely determine specific customer requirements and use them in construction projects. In construction, the relationship between a customer and contractor forms a multi-layer complex, with parties acting together and cooperating with other participants in construction. Collecting information about customer needs is very important to the improvement of products or services, as well 
elimination of problems and defects (KuJALA et al. 2001).

\subsection{Customer satisfaction evaluation}

The measurement of customer satisfaction has become one of the commonest most common formulas for managers and organizations, and comes from a wide variety of sources (LEPKOVA, ŽÜKAITĖJEFIMOVIENE 2012). A company must constantly measure the level of customer satisfaction to figure out how satisfied the customers are. Companies in construction all too often learn about the level of customer satisfaction too late, when a construction project is already underway. Meeting customer needs is most relevant in residential construction; the importance of customer satisfaction in the case of housing depends on the market intensity. When a company is aware of the features of its product or service that meet the customers' needs best, it can make marked changes in its services and products and thus, drive customer satisfaction up to the top (KÄRNÄ 2004). A survey of customer satisfaction is the main tool for assessing the quality of project execution, determining customer attitudes and getting feedback (RONDEAU et al. 2006). Satisfaction assessments help forecast the future behaviors of customers in light of customer loyalty (KÄRNÄ et al. 2004).

Customer needs can be determined through marketing research, customer surveys, analyses of customer concerns, or involving customers in all processes of projects that are already underway. Customer satisfaction is measured using a range of quantitative (direct or indirect surveys) and qualitative (a secret buyer, complaint management, target groups) criteria. Customer feedback by means of a questionnaire survey can be a very appropriate source of data. Disappointed customers often willingly name all reasons of their discontent and any defects (KOSKELA 2002).

In the USA, a technique was developed to determine the national American Customer Satisfaction Index (ACSI), which covers the assessment of 200 different companies on a 100-point scale from customer surveys. The ACSI model (Fig. 1) consists of the factors affecting satisfaction (perceived value, customers' expectations, perceived quality) on the left, the Customer Satisfaction Index in the center and the consequences of satisfaction (customers' complaints, customer loyalty) on the right. The ACSI is an important indicator of USA companies, macroeconomics and customer behavior.

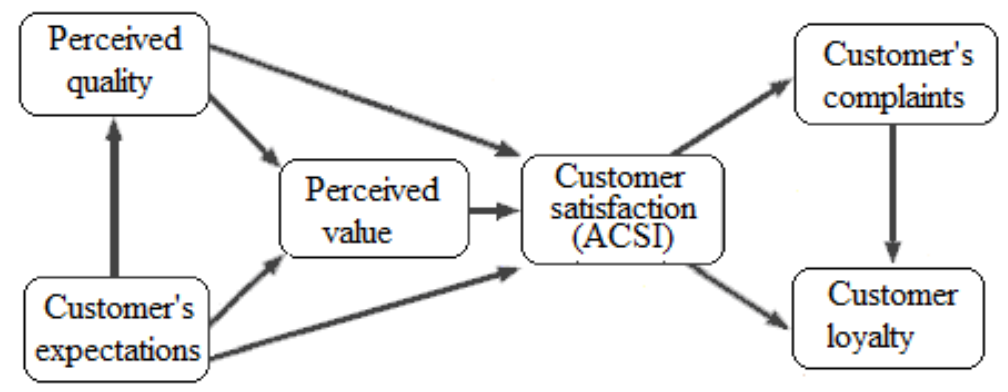

Fig. 1. The American Customer Satisfaction Index (ACSI). Source: THE AMERICAN... 2011.

To implement the public administration development plan for 2010, the Ministry of Environment of the Republic of Lithuania developed a calculation methodology for the customer satisfaction index. This means that the country is paying ever increasing attention to surveys of customer satisfaction, acknowledging their importance. Nevertheless, the measurement of customer satisfaction is not yet widely used as a tool for improving corporate performance. Treated as a standard customer survey, the measurement process of customer satisfaction can be divided into several main phases: planning, implementation, analysis of results, preparation of research findings and improvement (Fig. 2). Based on the experience of customer satisfaction measurements in some EU countries, the improvement of a customer service system can be defined as a cycle of service changes with the following main steps: assessing the current state (audit), measuring customer satisfaction, analyzing the results of measurements, summarizing the results, publication of the results, conclusions and improvements.

Summarizing customer satisfaction survey results means determining the customer satisfaction index. The Customer Satisfaction Index (CSI) is a mathematical expression of customer satisfaction through an indicator within the reviewed period. The index shows customer satisfaction in services and products as a percentage, $100 \%$ signifying complete satisfaction. The Customer Satisfaction Index tends to be higher for products than services.

The Customer Satisfaction Index Formula (1) is as follows (KOSKELA 2002): 


$$
\mathrm{CSI}=\sum_{i=1}^{n} w_{i} c_{i} ;
$$

where, CSI is the Customer Satisfaction Index, $\mathrm{n}$ is the number of quality parameters, $\mathrm{w}_{\mathrm{i}}$ is the importance of a given parameter, and $c_{i}$ is the evaluation.

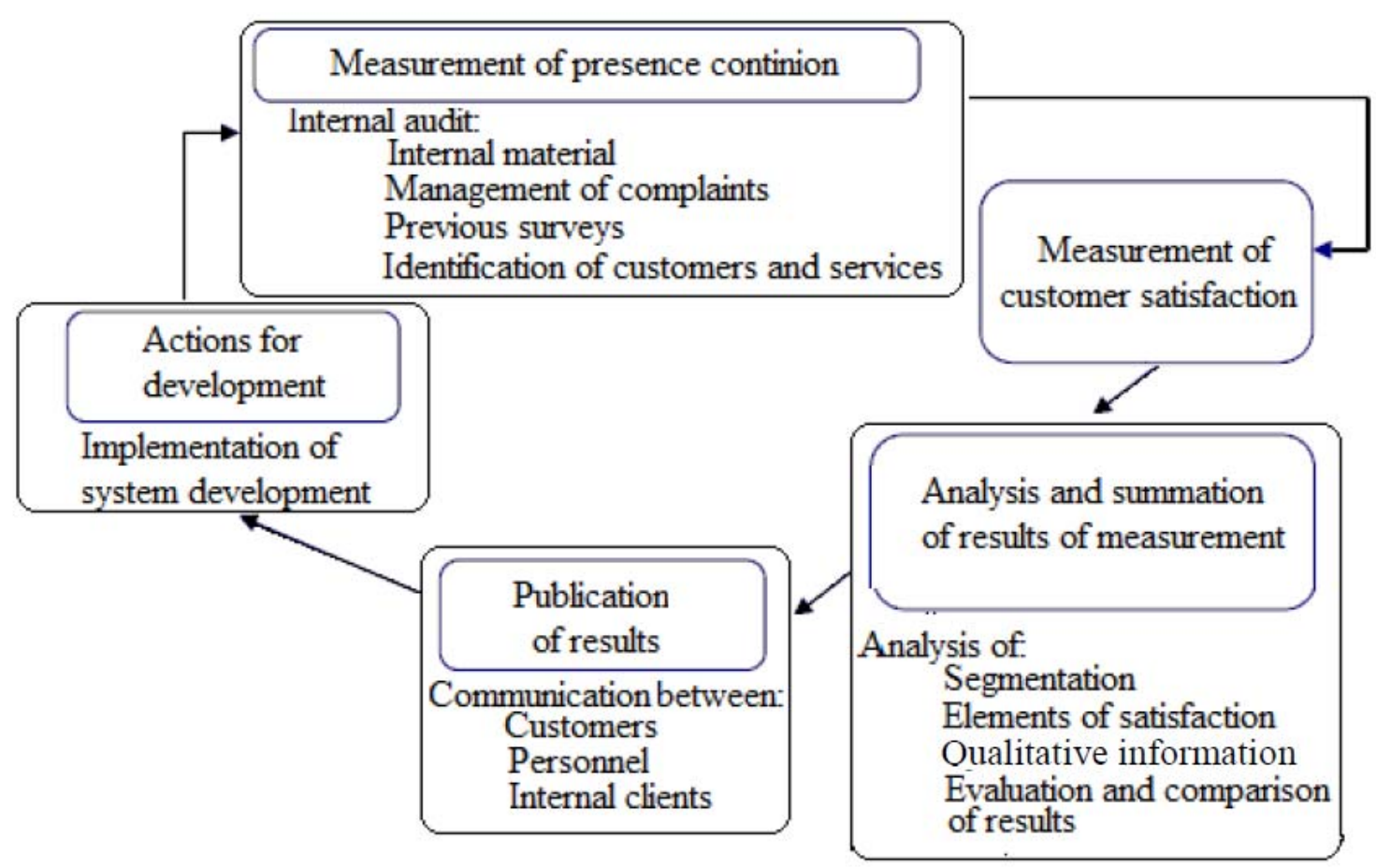

Fig. 2. Measurement of customer satisfaction. Source: VIEŠU̦JU PASLAUGŲ ... 2010.

Importantly, the concept of customer satisfaction has several key drawbacks: satisfaction is not constant and changes with new experiences; satisfaction is complex and is the result of several experiences before, during and after the assessment; satisfaction operates in a social context and, therefore, is versatile, shifting, and can also be unpredictable or indefinable; the reasons for satisfaction can be difficult to express, while determining the reasons for discontent can be easier; the inability to understand the causes of satisfaction poses a risk of construing "good results" as an excuse to change nothing (THIJS et al. 2008). Customer surveys barely touch on the technical aspects; they mostly reveal the quality of the end result and subjective customer opinions (RONDEAU et al. 2006).

More importantly, however, the measurements of customer satisfaction in construction also have benefits, as they reveal customer loyalty, the declining impact of prices on decisions, customer opinions and opportunities to improve them, stronger relations with customers, means of improving competitiveness, and competitors' strengths and weaknesses (ANDERSON et al. 2001). Productivity and customer satisfaction are precisely the key elements to achieving a compromise between quantity and quality.

\section{Quality in construction from a customer's perspective}

\subsection{Types of quality in construction}

The quality of services and products is not the same as customer satisfaction, though they are closely related. A quality-oriented corporate culture includes management process with clear end results. Before quality management processes are initiated, the significance of quality to a company must be defined, as well as its potential to fulfil customer needs and expectations. Quality can be defined as meeting specifications - a "degree" up to which a product or service must be without faults. More 
precisely, however, it can be defined as meeting and exceeding customer needs and requirements. The complete satisfaction of customers means not only responding to their needs but also delighting them (DIKAVIČIUS et al. 2003).

The construction sector has unique and own characteristics and qualities that differ it from other sectors (NURUL ... 2013). Quality in construction is often defined as quality that meets certain requirements and quality expressed through customer satisfaction. Quality within requirements shows the degree to which a construction product or service meets the design specifications. This definition of quality is mostly used by construction companies and contractors; such an approach, however, has its drawbacks with respect to the customer. A customer can be oblivious of or not interested in the mandatory specifications of a construction product or service, but expect the product/service to meet or even exceed the needs and expectations. On the other hand, quality within established requirements has the advantage of straightforward measurement and leads to efficient corporate activities (KÄRNÄ 2004). Quality is everything that attains and expands customer satisfaction expressed through the continuous, strategic, and economic assessment of products and services. This assessment covers such features as value, feedback, accessibility, long-term perspectives, sustainability and cohesion, innovations, and reputation (HOLT et al. 2000). From a customer's perspective, quality can be at one of three levels: unacceptable, acceptable and higher than acceptable (RONDEAU et al. 2006). Construction also includes functional, aesthetic, price (cost) and time aspects (BARRETT 2000). Customer satisfaction in the case of housing can be expressed through such elements as dwelling design, dwelling quality and dwelling maintenance (TORBICA et al. 2001). The key components contributing to the overall quality are as follows (KäRNÄ 2004):

- quality of the plan (idea),

- quality of the materials and technology,

- quality of the processes (functional quality),

- quality of the product or service after the sale (technical quality).

The quality of processes expresses the way a customer is rendered services and defines the manufacturing and consumption processes. Measurements of functional quality, however, cannot be as objective as those of technical quality, although functional quality is commonly considered paramount. A defect in the construction process, for instance, may have no impact on the technical quality from a customer's perspective as a result of proper management and problem handling. The quality of a construction product or service characterizes the quality of materials, equipment and technology, while the quality of processes characterizes proper project organization and the management of three main phases: design, construction, management and maintenance. The end quality of a product or service depends on its physical condition upon delivery to the customer, when cooperation with the builder ends. Construction quality can thus be defined as the overall quality of products and services. During a project, a customer evaluates the contractor's work by comparing it to his or her own expectations at certain phases (Fig. 3).

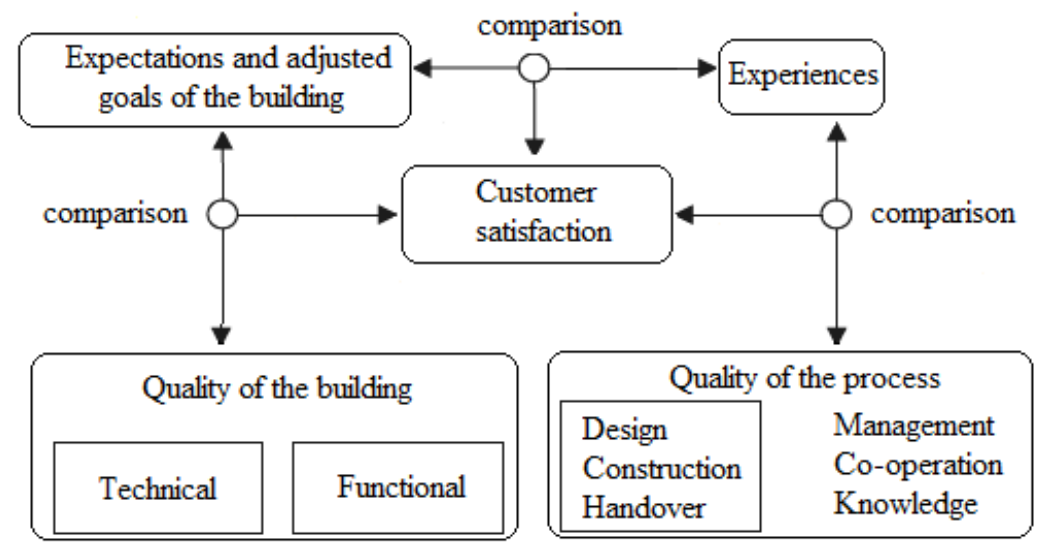

Fig. 3. Interrelationships between customer satisfaction and quality at the project level. Source: KÄRNÄ S. 2004.

The key elements to determining the interrelationships between customer satisfaction and product/service quality are as follows: the quality of the building, comparison of expectations and goals set for the building, comparison of the construction process and experience acquired during the 
process, and comparison of customers' expectations and experiences. Such concepts as after-sale support and appropriate actions are very important to the complete satisfaction of customers. The following perceptible components of quality can be distinguished: mastery and skills, attitude and behavior, accessibility and flexibility, reliability and trustworthiness, reimbursement, and reputation and credibility. Mastery associates with the possible results, reputation and credibility associate with the image and the remaining components of quality associate with the process.

From the customer's perspective, the following key elements to fulfilling customers' expectations can be distinguished: trustworthiness (the ability to deliver a service or product as promised), assurance (the knowledge and ethics of suppliers, the ability to evoke trust), material value (physical qualities of the product and support), empathy (personal concern and attention), and responsibility (the willingness to assist and ability to stick to the deadlines) (KOSKELA 2002).

The construction quality of buildings includes three main components: the quality of construction work $(40 \%)$, the quality of architectural work (50\%) and the quality of external work (10\%) (PHENG 2001). Quality also covers two main approaches: the absence of defects and the perceived perfection (RONDEAU et al. 2006). The requirements in regards to products, work and services are often determined considering the customers' needs, desires and expectations. It is worth mentioning that a high-quality construction product, such as a dwelling, must comply with construction regulations, requirements for design quality, structural design, appropriate management of construction processes and quality requirements for products and materials (HsIEH et al. 2006).

As mentioned, all possible dimensions of quality fall within one of two categories: quality in line with the customers' needs and quality meaning the absence of defects. A joint project by four European countries, i.e. Denmark, Estonia, Lithuania and Great Britain, attempted to define the key aspects of quality in construction and to adopt the quality management practices of more experienced countries in such countries as Lithuania and Estonia. The said project defined four elements of quality in construction, which covered such aspects as the environment, health, safety and dwelling location. Some aspects are driven by market mechanisms, while others must be regulated (ANDERSON et al. 2001).

Satisfied customers in construction, as in other industries, mean that a company is competitive and successful (BARRETT 2000). Measuring customer satisfaction with dwellings is important as a means of assessing the quality of housing and understanding the factors behind customer satisfaction or discontent. Satisfaction with dwellings relies on previous individual experiences of customers or significant persons in their lives considering the current situation of the housing industry (OLADAPO 2006).

A dwelling with appropriate physical and structural qualities does not necessarily possess good characteristics in view of the customer - opinions regarding the degrees of quality and satisfaction are subjective. Residential construction emphasizes the quality of both services and products. Cooperation with customers is very important; customers have been observed to be keen to pay more to companies that practice continuous quality control (in new construction and renovation in particular). The expectations of customers are continuously growing; they expect more open cooperation, flexibility and more transparent actions of builders. In addition to this, the process of the transfer for use requires responsibility, qualifications and an awareness of the indispensable duties and tasks. All actions must be pre-planned and coordinated with the customer, and all of the required documents must be ready (KÄRNÄ et al. 2009a).

The definition of quality pertaining to a building as a construction product is complex and heterogeneous. Professionals working in construction across Europe treat quality differently. Stakeholders in project implementation (designers, contractors, owners and customers) understand quality differently as well. The quality assessment of a construction product continues throughout the building lifecycle. Quality must, therefore, be analyzed as overall quality. The entire process must be divided into certain phases which can be assessed through the partial expression of quality. In construction, ensuring a complete system of quality for customers is very important.

Each customer is different and sees quality differently; thus the statement "no dissatisfied customers" does not necessarily mean that all customers are satisfied. Two aspects of quality are significant: simple quality and attractive quality.

We must keep in mind that, although quality often appears exaggerated to a manufacturer and a necessity to a customer, it is this opposition that may promote the use of new technology, as well as products and services of exceptional quality (KONDO 2001). While customers' needs grow together 
with the improvement of products, both processes are constantly interacting and stimulate mutual improvements. As needs exceed the available quality due to vast human imagination, growing needs are the main reason propelling quality improvements.

\subsection{Estimation of quality in construction}

Customer satisfaction can be one of the main means of assessing quality improvement in construction. Customer satisfaction is also one of the principal elements in total quality management, which underlines complete satisfaction through the ongoing improvement of products and services. Construction companies increasingly use total quality management, although construction has been struggling with implementation because of failure to determine and apply customer needs properly. Customer-orientation, communication skills and response to complaints are of particular importance to the complete satisfaction of customers in construction.

To maintain customer feedback, a company must accumulate information after each completed construction project. Finland, for example, established the Association of Quality in Construction (RALA), which collects data about customer satisfaction via mandatory questionnaires to be filled in by each customer of a completed construction project (end user or contractor, if subcontractors were hired) immediately after it. Such a customer feedback model (Fig. 4) is instrumental not only in scientific research, but is also used as a practical tool to ensure cooperation of different parties in the construction process. This helps accrue more objective information about customer feedback than via own customer surveys of contractors.

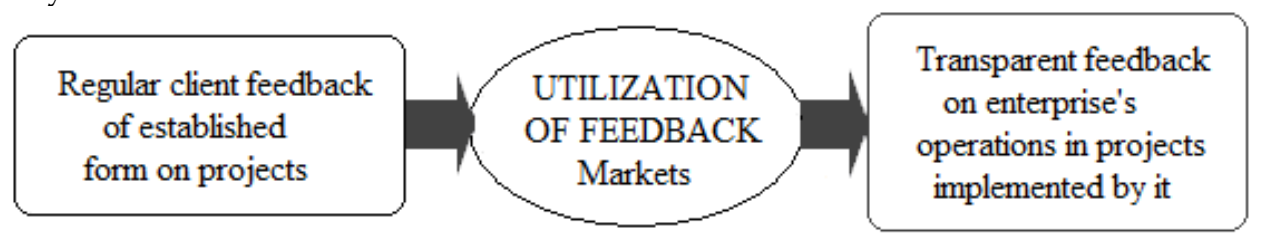

Fig. 4. RALA's feedback system. Source: KÄRNÄ S. 2004.

Organizations operating in the Lithuanian construction sector would benefit from a customer feedback model (Fig. 4) which could provide them with information about customer satisfaction, and help them make appropriate decisions and improve the quality of their services and products. A company aiming to assess quality needs to develop a global quality assessment system, which ought to include the following aspects: as high customer satisfaction as possible, appropriate quality management and prevention, continuous quality assessment in construction projects, continuous quality improvement in construction, and decreasing quality costs. To ensure quality, it must constantly be measured, its results compared, and the trends of quality changes determined. This enables actions to be corrected and proper quality levels maintained (DIKAVIČIUS et al. 2003).

Customer satisfaction is an effective way for companies to stand out among competitors and gain a competitive edge. Construction companies get the following benefits from customer satisfaction: improved cooperation and mutual agreement of parties, determined need to improve the quality of processes, a better understanding of problems, the possibility of assessing the progress towards a goal, management of and reports about the achieved results, possibilities of introducing changes, increased sales, satisfied customers along with their loyalty, and a better corporate image.

Discontent and disappointed customers can make a company suffer extensive external losses, such as the costs of complaint reviews, attempts to lure back customers, or warranty services (BAGDONIENĖ et al. 2004). Companies are often willing to implement those aspects of total quality management that are directly related to financial welfare and competitiveness. But quality improvement in itself leads to improved competitiveness, a stronger position in the market and better productivity; this can only be achieved if customers are satisfied with the quality of products and services (HAUPT et al. 2004).

\section{Analysis of the residential real estate market in Lithuania}

\subsection{Uniqueness of the residential segment}

Housing is the second most important human need, as well as a considerable national asset. Housing of good quality is the basis for a solid society and social coherence, while conveniences, problems and the quality of dwellings are closely interrelated with urban development and the national economic situation (OLADAPO 2006, ŹRÓBEK et al. 2015). The concept of an ideal dwelling lies not only in the 
technical, architectural and engineering components, but also in the social, behavioral, cultural and individual features of dwelling occupiers and the conditions of facility management (JIBOYE 2009).

Customers in the Lithuanian housing sector are faced with purchase problems. When future occupiers buy designed but not yet constructed buildings, which happened in Lithuania in times of an active housing market and higher purchasing power of housing buyers, builders commit to deliver housing of appropriate quality in the future, though such commitments are not always fulfilled. Customers then feel disappointed and, despite being dissatisfied with the quality of dwellings, have limited chances to see their loss and dissatisfaction reimbursed. For the above reasons, customers try to buy housing in constructed buildings, preferably in those certified for occupancy. In such a situation, customers have more possibilities to handle problems as they occur or choose housing in a different building if the stated characteristics of the product or quality of the dwelling vary from the needs of their occupiers (ENCIUS 2008).

Competition in construction encourages construction companies to do their best. Most construction companies obtain qualification certificates, abide by the construction rules and strive to maintain quality when implementing the solutions set forth in the construction design documentation. On the other hand, even though the contractor/builder is responsible for the end product, the quality of construction depends on the experience and the work quality of the selected subcontractors. The builder/principal is responsible for the work and quality achieved by contractors and subcontractors, making certain that they eliminate defects or reimburse loss when necessary (MINIUS et al. 2008). This means the main contractor should choose only contractors with similar attitudes towards quality and customer satisfaction, and prices of labor that match the quality. A customer sees progress only if the value and quality are improving while the price is dropping. Good work on the first try notably drives down the ultimate cost of an investment.

Quality in construction starts dropping along with a considerable increase of productivity. A large amount of construction projects means less attention paid to quality; with all the extra work, agencies in charge of quality control may also do an inferior job. Construction standards and construction supervision agencies must ensure the quality of a building, but with a boom in the real estate market, the quality of buildings inevitably suffers. Cost saving, cheaper materials and products, unskilled workers, very fast construction, and too short of deadlines are not only the reasons behind poorer quality in construction and completely forgotten needs and expectations of customers, but also lead to violations of construction requirements and defects in buildings. Occupiers, however, may not notice the defects until a few years later, when a significant number of builders are already non-existent or in bankruptcy proceedings, meaning that their liability to customers is void.

Furthermore, cases of corruption are not uncommon in construction. An engineer in charge of technical supervision often can be a representative of the builder or contractor from a spin-off company. The same builder, therefore, is responsible for the project, construction, sales and control. It is important to note that quality in commercial construction is often better, because it is relevant to builders themselves, as they often use such buildings to rent out office space. Residential buildings are constructed for quick sales and their quality is, therefore, inferior (KUČINSKAITE் 2007).

The following main reasons of poor housing quality can be distinguished in Lithuania: a skyrocketing boom in the real estate market, a notable increase in the amount of construction projects, cost saving on materials and products, attempts to get higher profits, fast construction, unfit design solutions, a shortage of workforce, poor skills, the absence of quality, negligible practice of quality improvement and defect elimination, and corruption and bureaucracy.

Construction companies respond to customer complaints in different ways: those willing to retain goodwill try to eliminate any defects quietly and immediately; others are not so quick at problem solving and leave it up to the occupiers, who are then absolutely dissatisfied and either try to force the company to handle the problems or eliminate the defects at their own expense, expecting the reimbursement of loss. Some customers register complaints on their own. The National Inspectorate of Territorial Planning and Construction under the Ministry of Environment of the Republic of Lithuania, for instance, received some complaints from occupiers of new buildings constructed between 2006 and 2009 (VARTOTOJŲ TEISIŲ ... 2009). Although expert examinations of construction quality were not initiated, the actual data were inspected on-site in the construction works.

In Lithuania, a quality dwelling means that it meets the key requirements and corresponds to customers' needs under the Construction Technical Regulation. Quality standards are in place to prevent discrepancies in production throughout the construction process. The bottom-line in the Lithuanian 
standard of procedures - ISO 9001: 2008 (LST EN 9001:2008) - is an approach applied to all operations of an organization (LST... 2008). Thus, a construction company follows the model of a quality management system and can control the quality of design, manufacturing, products and services. It should be noted that a builder is liable for the quality of a house certified for occupancy and provides warranty services until the term expires. On the other hand, a builder in bankruptcy is no longer liable to provide warranty services. Customers remain protected only if the builder was insured, as the insurance company then takes over the liability for the building. If a new building is not certified for occupancy, it cannot be used and an occupier can only file complaints about the defects or poor quality to institutions in charge of certification for occupancy, and must specify the defects to be removed prior to such certification. It must be noted that, even when certified for occupancy, a building is not necessarily of good quality from the customers' perspective and does not necessarily meet the customers' needs.

\subsection{Residential market in Lithuania}

The need to own a dwelling instead of renting one is observed as prevailing among customers in Lithuania. The data (2008) of Eurostat - the EU statistical agency, showed $87.8 \%$ of families in Lithuania to own a dwelling, while the EU average is only 62.7\% (ČIULADA 2008). According to the data from the Real Property Cadaster and Register of the State Enterprise Center of Registers, as of 31 December 2014, the stock of dwellings amounted to 87.9 million $\mathrm{m}^{2}$ of useful floor area (55.5 million $\mathrm{m}^{2}$ - in urban, 32.4 million $\mathrm{m}^{2}$ - in rural areas). Private ownership accounted for 98.1 per cent of the dwelling stock, with state and municipal ownership accounting for 1.9 per cent. (Statistics Lithuania, 2015). The number of constructed residential buildings during 2000-2009 has been shown in Fig. 5.

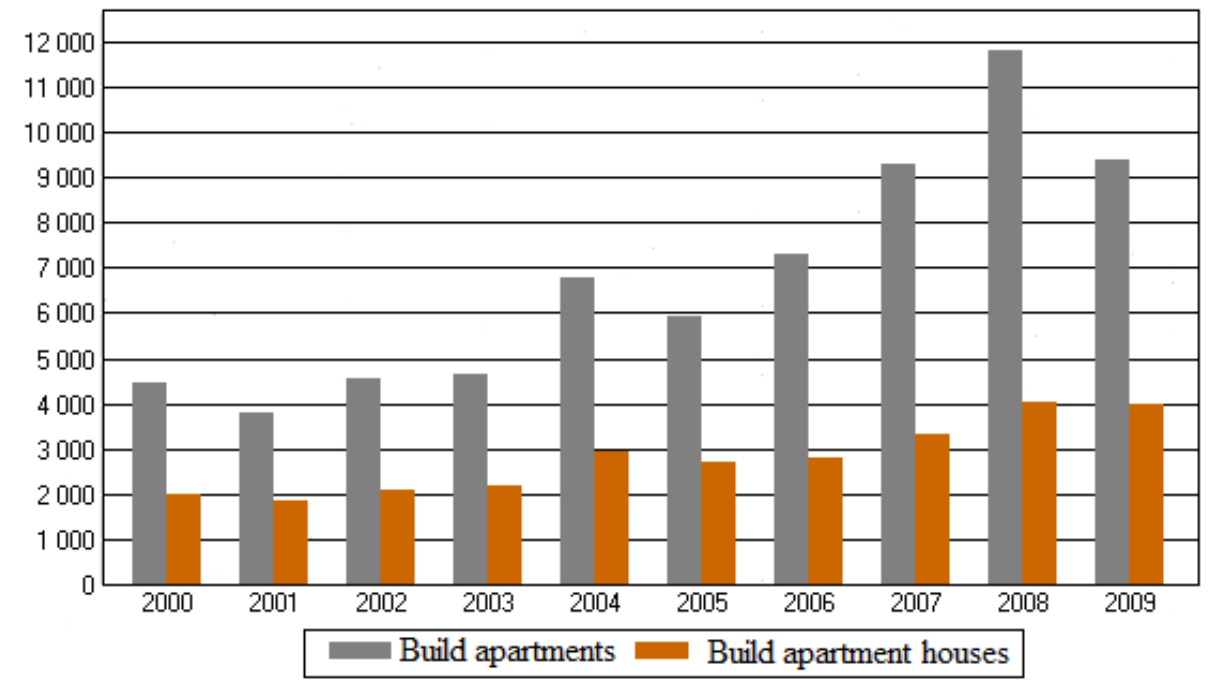

Fig. 5. Number of constructed residential buildings in 2000-2009. Source: STATISTIKOS DEPARTAMENTO... 2011.

Almost 4,000 new buildings and 9,400 new apartments were built in 2009, according to Statistics Lithuania (Fig. 5). The number of new apartments dropped by $21 \%$, and new buildings by $2 \%$, year-on-year. 2009 also saw a $12.1 \%$ year-on-year drop of investments in residential buildings, including money to buy dwellings. In 2009, new construction made up 44.5\% of all types of construction work. Importantly, 57 new apartment buildings (three apartments or above) providing 1,321 new apartments, with an average useful area of 74.2 sq. m, were approved for construction in 2009 (MATERIALINĖS INVESTICIOS ... 2010) - a year-onyear decrease of as much as $81.8 \%$. The final number of building permits issued for the said apartment buildings was 56. Some 128 apartment buildings and 5,398 apartments were certified for occupancy in 2009 a decrease of $30.8 \%$ as compared to the previous year. In the context of other EU countries, the Lithuanian economy has recently experienced a very rapid expansion lasting several years. The process slowed down in 2008, thus contributing to the changes in the Lithuanian housing market. The year 2008 can be considered "the breaking point" of the housing market. Falling prices of dwellings and numbers of deals recorded at the start of the year continued dropping throughout the entire year. In 2008, the prices of new construction apartments in the capital city of Vilnius dropped by $20 \%$. In 2009, the prices in Lithuanian cities fell by $27 \%$ (in 2008, the percentage drop was almost twice lower, i.e. 15\%) 
(GYVENAMOJO NEKILNOJAMOJO ... 2009). As the prices were dropping, the number of deals also fell, plunging to a three-year record low. 2008 saw the number housing transactions in Lithuania fall by a third. The number of housing transactions in the capital city of Vilnius was 30\% lower than in 2007.

The number of transactions almost halved in the first half of 2009, year-on-year. In Q2 2009, the number of houses sold dropped by about $50 \%$, the number of apartments - by almost $55 \%$, and the average number of all transactions - by 53\% year-on-year. In Q1 2009, the number of housing transactions in Lithuania was the lowest in six years (2.5 times below the average for the same quarter in the years from 2004 to 2008). As compared to 2008, the number of housing deals in 2009 dropped by $42 \%$ in Lithuania and by $44 \%$ in Vilnius (REAL ESTATE... 2010). The numbers of dwellings constructed in the period 2010-2014 have been shown in Table 1.

Table 1

Number of constructed dwellings in 2010-2014 (Statistics Lithuania, 2015)

\begin{tabular}{cccccc}
\hline & $\mathbf{2 0 1 0}$ & $\mathbf{2 0 1 1}$ & $\mathbf{2 0 1 2}$ & $\mathbf{2 0 1 3}$ & $\mathbf{2 0 1 4}$ \\
\hline Dwellings, total, thous. & 1270.0 & 1282.5 & 1289.1 & 1298.0 & 1308.7 \\
\hline $\begin{array}{c}\text { Dwellings per 1000 population } \\
\text { Average useful floor area per } \\
\text { dwelling, m2 }\end{array}$ & 416 & 427 & 434 & 441 & 448 \\
\hline Dwellings, \% & 65.9 & 66.4 & 66.6 & 66.9 & 67.2 \\
\hline Urban areas & 100.0 & 100.0 & 100.0 & 100.0 & 100.0 \\
\hline Rural areas & 69.8 & 69.7 & 69.6 & 69.4 & 69.3 \\
\hline & 30.2 & 30.3 & 30.4 & 30.6 & 30.7 \\
\hline
\end{tabular}

Source: STATISTICS LITHUANIA 2015.

\section{Study of customer satisfaction with living conditions in new apartment buildings}

\subsection{Research data}

A questionnaire method (online questionnaire survey) was selected for the study of customer satisfaction with new apartment buildings. This method guarantees low survey costs and quick research results. The questionnaire included 23 main questions and 14 auxiliary questions, the latter of which were only to be answered in the case of certain answers to some of the main questions. The questionnaire aimed to assess customer satisfaction with their dwellings and the quality of dwellings in new apartment buildings (constructed in 2000 or later) in Vilnius, the capital of Lithuania. The target group for the research were adults (16 years or older) living in Vilnius in new apartment buildings, irrespective of their housing tenure; 30 respondents took part in the survey. The survey focused on such key areas as: the quality assessment of dwellings (technical and functional aspects, economy), customers' satisfaction with warranty services and the builders' readiness to cooperate, customer expectations, the assessment of overall customer satisfaction and its consequences (customer complaints, customer loyalty, recommendations to other customers). The initial diagram of the survey has been shown in Fig. 6.

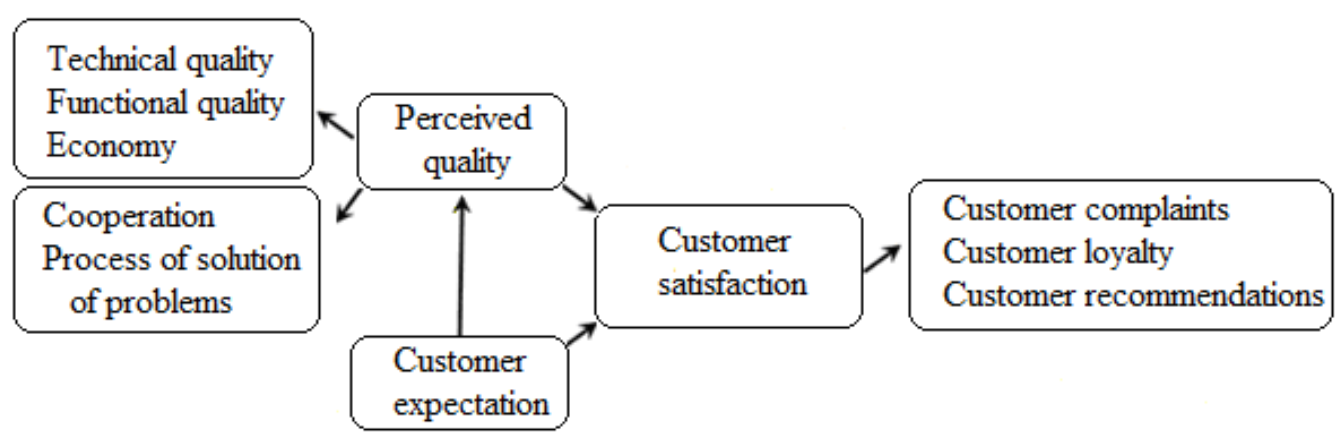

Fig. 6. Components of customer satisfaction. Source: Own study.

\subsection{Analysis of respondents and apartment buildings}

The customer survey revealed the respondents to be mostly young people aged between 21 and 30 
$(80 \%)$, and between 31 and $40(17 \%)$. Only 3\% of the respondents were between the age of 41 and 50 . Most of the respondents had been living in their new dwellings for 1 to 2 years (53\%) or 3 to 5 years $(23 \%)$. As a result of the short term of residency, the majority of defects in their new dwellings may still remain hidden, which complicates assessment from the technical perspective. On the other hand, buildings constructed earlier may be of better quality and those who have lived in their dwellings longer may experience fewer defects than those living in buildings with violations already recorded in the construction phase. Some $13 \%$ of the respondents had lived in their new dwellings for less than a year, $10 \%$ - for 6 to 8 years. The majority of apartment buildings in question were constructed between 2006 and 2009 (67\%), followed by those constructed in 2004-2005 (23\%), and finally those in 2000-2003 (10\%). The construction of new apartment buildings started increasing in 2004 and the new housing sector expanded rapidly from that time. The majority of buildings in question were constructed 1-6 years ago, thus some technical defects of buildings may already be observable. However, this also depends on the fact of how long the respondents had been living in their dwellings. The buildings should be still covered by the warranty; of course, this applies only if the buildings were certified for occupancy when their construction was proclaimed to have been completed.

It is worth noting that the majority of dwellings in question either belong to banks via mortgage loans (43\% of respondents) or are owned by the customers or their relatives $(40 \%)$. A smaller group of respondents rent their dwellings. Respondents who are property-owners are likely to be more interested in the quality of their dwelling and satisfaction of their needs. Any user, however, can notice the main technical and functional defects, and assess the quality of housing. Such an assessment can be handy in the future to make decisions on the most appropriate dwelling of the best quality that best satisfies needs. The majority of respondents (83\%) live in apartments between the ground and top floors. Thus, neither the top floor (occupied by $14 \%$ of respondents) nor the ground floor (3\% of respondents) is considered to be the most comfortable and the best suited for meeting the customers' needs.

The apartment buildings in question were grouped according to the residential areas of Vilnius, their builders/principals considered in the survey, and by the main construction projects. The survey determined 18 main builders, among which two companies had financial difficulties and were being restructured and another two companies were marked as bankrupt in the database of the State Company Centre of Registers (Registru Centras VI), though the warranty term was still running. This means that customers may sometimes have no one to address in the case of dwelling-related problems unless the builders/principals had insured their activities. Among the apartment buildings assessed in the survey, $83 \%$ had been certified for occupancy and 3\% had not. Hence, the majority of houses are still covered by the warranty, and warranty services are mandatory. Curiously, $14 \%$ of respondents were not aware of whether or not their house had been certified for occupation. This illustrates the lack of initiative among customers; problem handling, if needed, is therefore slow. Not all customers are active in defense of their needs and expectations.

\subsection{Quality assessment of new apartment buildings}

The quality of housing in new buildings may be assessed from several perspectives. The most important among them being economic efficiency (e.g. low maintenance costs), technical quality (e.g. energy efficiency, sound and thermal insulation, absence of defects) and functional quality (e.g. layout, location, access, area), as well as the environment. Customers in search of new dwellings base their choices on the following expectations:

- economy (37\%),

- better technical characteristics $(24 \%)$,

- better contemporary living conditions, better layout, space, design (32\%),

- prestige and image $(7 \%)$.

A choice of a new dwelling, in most cases, is therefore determined by economy, followed by its functional and technical characteristics. Other reasons include a suitable location of the building, the environment, the superiority of dwellings in old construction, the presence of a lift in a 5-storey building and young neighbors. The aspect of economy is paramount to customer satisfaction, followed by the functional aspect, while the technical aspect is somewhat less important. This proves that customers often do not consider the technical quality of a building to be that relevant. Customers take the technical characteristics for granted and base their quality assessments on correspondence to 
modern living conditions, layout and design. Interestingly, customers named economy as the main reason in the choice of their dwelling, followed by functional quality. This means that customers choose affordable, cost-efficient dwellings, but upon buying, start to consider its quality, as well as technical and functional properties. Hence, those customers who either buy dwellings without full prior knowledge of the situation or buy dwellings which have not yet been constructed or certified for occupancy, can end up disappointed.

Prestige or image, demonstrating the financial capacity to afford a dwelling in a new building, least concern the customers.

We shall proceed with the research findings determined by analyzing each quality indicator of dwellings separately. However, it is important to note that the economy indicator, the assessment of which is too complicated, was left out of this analysis and not considered in the overall evaluation of customer satisfaction. From the customer perspective, the economic aspect depends on the financial situation of customers, the national economic situation, the economic situation in the real estate market at different times, the costs of facility management and maintenance, the installed heating system, and various needs of customers.

\subsubsection{Technical quality}

Customers consider the technical quality of their dwelling to be one of the most important aspects, but struggle with its precise assessment because they lack relevant technical knowledge. During the survey, our respondents assessed the technical indicator by awarding points from 1 (least important) to 4 (most important). The average given to the technical aspect by all customers was 3.67. The technical quality of housing was assessed considering customer satisfaction with their dwellings as well as common areas and facilities. The newly constructed dwellings in question are mainly sufficient $(47 \%)$ or average $(30 \%)$ in terms of meeting needs; a smaller portion satisfy the inhabitants' needs fully $(20 \%)$, with only $3 \%$ of customers claiming to be completely dissatisfied with their dwellings. Customers are mostly discontent with high maintenance costs and construction defects in buildings already certified for occupancy, as they are then less inclined to change anything or stir problems. Hence, customers, though disappointed, have few possibilities and little willingness to change anything. Builders who elude handling problems and liability are mostly responsible for such a situation. Furthermore, half of the discontent customers never informed the builder about the problems they were experiencing. The other half applied on several occasions, but the builders offered poor warranty services and ignored complaints.

Over time, dwellings also tend to become inadequate as the number of family members starts to increase. People are more satisfied with common areas and facilities (lifts, stairwells, garages, etc.). Common areas meet needs well or fully (90\%). Thus, customers are more satisfied with common areas than their actual dwellings. This may be explained by the fact that common areas are less significant. The main faults of common areas reported by the respondents are the constant failure of garage doors and gates, poor design of stairwell entrances, and bad access to the underground parking.

The following visible defects of new apartment buildings can be distinguished:

- cracks in walls and ceilings, fractures (18\%),

- condensation on windows, misting (18\%),

- poor sound insulation $(14 \%)$,

- improper finishing of the facade $(11 \%)$,

- poor ventilation $(10 \%)$,

- defects in common areas $(8 \%)$,

- defects in balconies (5\%),

- defective roof covering (3\%),

- moisture, mold (1\%),

- poor thermal insulation $(1 \%)$,

- poor precipitation drainage $(1 \%)$,

- other (defects in ventilation shafts, wind noise, windows of bad quality) (9\%).

Only $1 \%$ of respondents having lived in their dwellings for 1-2 years noticed no defects. Those dwellings had been built in 2008-2009. We can presume that the defects were not identified due to the short time of their existence. Recently the respondents started complaining about the poor quality of buildings, defects or necessary repairs. Most of the respondents $(60 \%)$ reported making a complaint 1-2 times about poor quality and defects, and $6 \%$ of the respondents complained for the same reason more than 3 times. 
This shows that defects are rather abundant in newly constructed dwellings. A number of respondents did not complain, considering the defects to be a minor problem, were expecting someone else's (e.g. the neighbors') initiative to be taken for dealing with the problem concerning the defect, or feared a negative reaction from the builders.

Real estate is not easy to change or buy due to financial circumstances; therefore, if the customers once had a bad experience in having a defect eliminated by the builder, or did not receive any reimbursement in connection with the above problem, they would probably not attempt to complain again. To sum up the defect problem, the following reasons for not reporting them must be enumerated: the defect was not too important, insufficient experience in making complaints, the ability of the builder (contractor) to evade liability (dwellings were not certified for accommodation, bankruptcy of the construction company, etc.). A dispute with the builder or construction company may require a lot of effort, sometimes leading to a serious struggle which can even end up in court. Nevertheless, the discontent customer may have an ill effect on further projects carried out by the builder/ the construction company.

\subsubsection{Functional quality}

In the survey, the respondents evaluated the indicator of functional quality by awarding points from 1 (least important) to 4 (most important). The average for the functional aspect by all customers was 3.37. This value is $9 \%$ lower than that of the technical quality indicator. Customers distinguish the following main factors of poor functional quality in newly constructed dwellings:

- lack of parking places for cars $(22 \%)$,

- too close proximity of neighboring houses/apartment buildings (19\%),

- lack of plants and green areas $(17 \%)$,

- poor access $(10 \%)$,

- poor courtyard infrastructure (8\%),

- poor dwelling layout (5\%),

- other (unfinished construction nearby, poor access due to inadequate parking; $5 \%$ ).

A considerable portion of the respondents did not encounter any functional faults (14\%), though on a case-to-case basis for each indicator, some functional defects were specified. The majority of the respondents are satisfied with the layout, which corresponds to their needs perfectly or fairly well $(87 \%)$. This may be explained by the fact that the layouts are often modified to suit the buyers, or that dwellings with the most suitable layout are chosen and purchased.

Furthermore, the majority of the respondents are satisfied with the location and accessibility, probably because they set their mind on and adapt to the location of their future home in advance, when considering buying a dwelling. Only $3 \%$ of the respondents feel that the location is bad, while others give positive reviews for the same location. People are mostly discontent with a certain location due to the lack of public transportation and cars being the only means of reaching their homes. However, the majority of customers are satisfied with access and infrastructure. Only a few respondents (particularly those who often use public transportation) are absolutely discontent $(10 \%)$. Too small of a courtyard, the lack of green areas, too small playgrounds, too few trees, an absence of benches, a shortage of car parking places and difficulties with access are also reasons for expressing discontentment.

The issue of parking places is generally important but ambiguous. Customer satisfaction with the space available for parking is average or high $(80 \%)$. These respondents are likely to have bought a parking place. The remaining discontent respondents have strong reasons to support their negative feelings on the issue: paid car parking (not inclined to pay, too expensive), no car parking whatsoever even though such had been planned, the inability to afford a parking place, and parking places occupied by vehicles of employees from nearby offices rather than residents.

Safety is another important indicator of the functional quality. The survey determined that the respondents feel safe in their dwellings and express either average or complete satisfaction with the safety measures in their apartment buildings. A handful of respondents (3\%) found safety to be at variance with their needs, particularly in common areas such as garages.

\subsection{Evaluation of warranty services and builder's readiness to cooperate: the case of new apartment buildings}

During the survey, the respondents evaluated the warranty services and the builders' readiness to cooperate with points from 1 (least important) to 4 (most important). The average amount of points 
awarded by the purchasers of dwellings was 2.07. Hence, this indicator is less significant than the functional and technical condition of the building. The majority of respondents who complained to the builder about defects at least once considered the warranty services to be good or average (64\%). On the other hand, $28 \%$ of occupiers considered the maintenance services provided by the builders to be poor or very poor. It is important to note that the opinions of customers about the warranty services and problem handling by the builder are very diverse. Evaluations of the same builder, for instance, can be ambivalent: either strongly positive or absolutely negative. Hence, customer opinions are subjective and only the overall results ought to be analyzed.

The surveyed respondents considered the response of builders/principals to their complaints to be either average $(55 \%)$, delayed or absent $(28 \%)$, or timely $(19 \%)$. It is important to note that several respondents evaluating the same company had very different opinions, some stating that it responds to complaints in a timely manner, while others that it never responds. Once again, this proves that the opinions are subjective and depend on individual treatment and cooperation with the customer.

\subsection{Calculation of customer satisfaction index and loyalty measurements}

In an attempt to measure the level of customer satisfaction, the customer satisfaction index was calculated using the survey results and having considered the functional and technical quality of the dwellings, warranty services and the builders' readiness to cooperate with the inhabitants. Customers assessed their satisfaction for each of the above-mentioned indicators on a scale from "excellent" to "very poor". The ranking was based on points from 1 to 5 , with 1 being the lowest and 5 the highest:

- 5 for excellent (100\% satisfied),

- 4 for good (75\% satisfied),

- 3 for average (50\% satisfied),

- 2 for poor (25\% satisfied),

- 1 for very poor ( $0 \%$ satisfied).

The customers' assessments were used to calculate the Customer Satisfaction Index (CSI) by using Formula (1). All interim indices and the final index of customer satisfaction have been given in Table 2.

Table 2

Customer Satisfaction Index

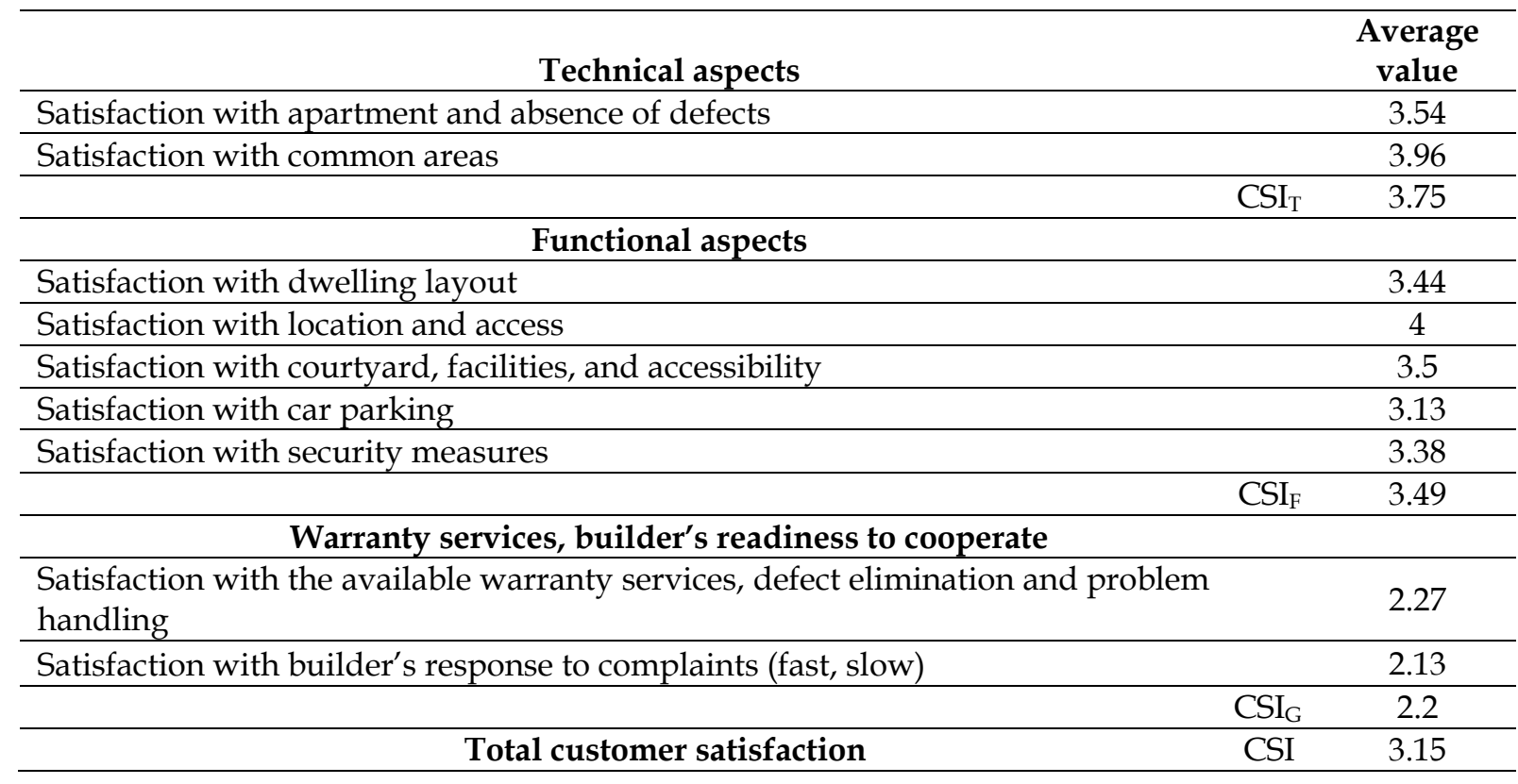

Source: Own study.

The indices of satisfaction for each indicator show the highest scores to have been attributed to the technical parameters of dwellings and common areas, despite the defects specified; the $\mathrm{CSI}_{\mathrm{T}}$ is 3.75 points (75\% satisfied). Functional parameters fare worse, with a $\mathrm{CSI}_{\mathrm{F}}$ of 3.49 points (69.6\% satisfied). The warranty services and the builders' readiness to cooperate are ranked the lowest; the CSI for $_{\text {this }}$ 
indicator is only 2.2 points, and thus below average satisfaction. Hence, customers are completely discontent and builders, in view of this, must immediately start improving customer service and warranty services to meet at least minimal customer needs.

On a 5-point scale, the average customer satisfaction amounts to 3 points. This means that the total Customer Satisfaction Index (CSI), is slightly above 3.15 points, which shows the average satisfaction $(63 \%)$ of customers with dwellings in new apartment buildings. In evaluations of customer satisfaction, customer loyalty is also an important indicator. Customer loyalty was assessed with 1-3 points (1 - not loyal, 2 - average loyalty, 3 - completely loyal). Customer loyalty was assessed considering their desire to exchange their dwelling for another, better suited to their needs irrespective of the possibilities ( 1 - more than a few times, 2 - only a few times, 3 - never wished to do so), readiness to make a recommendation to other customers ( 1 - absolutely not, 2 - maybe, 3 - surely), and loyalty as stated by the customers themselves. The results of customer loyalty have been shown in Table 3 .

Table 3

Customer Satisfaction Index

\begin{tabular}{|c|c|}
\hline \multicolumn{2}{|l|}{ Evaluation of loyalty (1-3 points) } \\
\hline Willingness to change the dwelling & 2.01 \\
\hline Readiness to make a recommendation to other customers & 2.6 \\
\hline Loyalty as stated by the customers themselves & 1.64 \\
\hline Total loyalty & 2.08 \\
\hline
\end{tabular}

Source: Own study.

The results show customer loyalty to be $69.33 \%$, and thus only slightly above average; this means that the customers have average loyalty to their dwellings, which is an important sign to builders. It is the builders who must attempt to satisfy customers' needs so as to gain higher loyalty. On the other hand, loyalty depends as much on warranty services and personal reasons as on the good quality of dwellings that meet the customers' needs. The desire to move, for instance, can be conditioned by a change in the customers' life situations, financial capacities or attitudes, rather than poor quality.

Many respondents would not change their dwelling (40\%), though quite a few considered changing at the first favorable moment, more than several times (27\%). Over half of the respondents $(54 \%)$ considered changing their dwelling at least once. Interestingly enough, the majority of these respondents said they were satisfied with their dwellings. Consequently, the desire to change the place of living springs from a change in the living situation - either the dwelling is temporary, or the customers are not fully satisfied with it. This fact highlights that completely satisfied customers differ greatly from those exhibiting average satisfaction. If an opportunity arises or better conditions turn up, customers with average satisfaction will leave their dwellings. Respondents who are fully satisfied with their dwellings said they had never considered changing them.

The majority of respondents would certainly recommend or possibly recommend their dwelling to another customer. A paradox, but even those respondents who would like to find a new dwelling and are not satisfied with their current one, said they would recommend, certainly or possibly, their dwelling to other customers. Thus, a large part of the respondents believe that a dwelling they find unsuitable for themselves would suit others. This demonstrates a difference in needs, as well as the subjective or contradictory opinions of customers.

A large portion of the respondents say they are loyal to their dwellings $(47 \%)$, but many others think they do not fall under such description. Others still believe that loyalty is impossible in the housing sector, as needs change with time, and would move to a new dwelling, but not because the old one was bad or failed to meet their needs. Many respondents who often consider moving to a new dwelling still consider themselves to be loyal. Conversely, some respondents who are really satisfied with their dwelling and do not consider moving think they are not loyal. Consequently, if real estate were more accessible, customers would certainly take the opportunity to find a dwelling better-suited to their needs. On the other hand, some respondents do indeed confirm the fact that a satisfied customer is a loyal customer.

\subsection{Customer satisfaction matrix}

The survey findings can be used to build up a matrix of customer satisfaction accounting for the 
importance of indicators and the degree of customer satisfaction (Fig. 7). The index of customer expectations must be the highest on a 5-point scale, because customers hope that the new dwelling will correspond to their main needs. Importance was calculated using a score from 1 point (least important) to 4 points (most important), based on the customers' expectations and motives for choosing a dwelling in a new apartment building. Economy (3.53 points), functional quality (3.33 points) and technical quality (3 points) were found to be the most important factors; the warranty services and the builders' readiness to cooperate (2.13 points) were the least important. Considering the average values of satisfaction and importance, the above diagram can be divided into four main quarters. Quarter I shows the achieved goals and strengths. This means that companies must maintain the same level of technical and functional quality in new residential buildings. Quarter II shows the first priority for improvements and the necessary actions. Quarter III shows the second priority, which covers the improvement of warranty services and cooperation, better customer services, faster responses to complaints and problem handling. Appropriate customer relations and continuous benevolent cooperation often offset technical or functional defects. Quarter IV shows the third priority, which defines operating advantages and optional strengths.

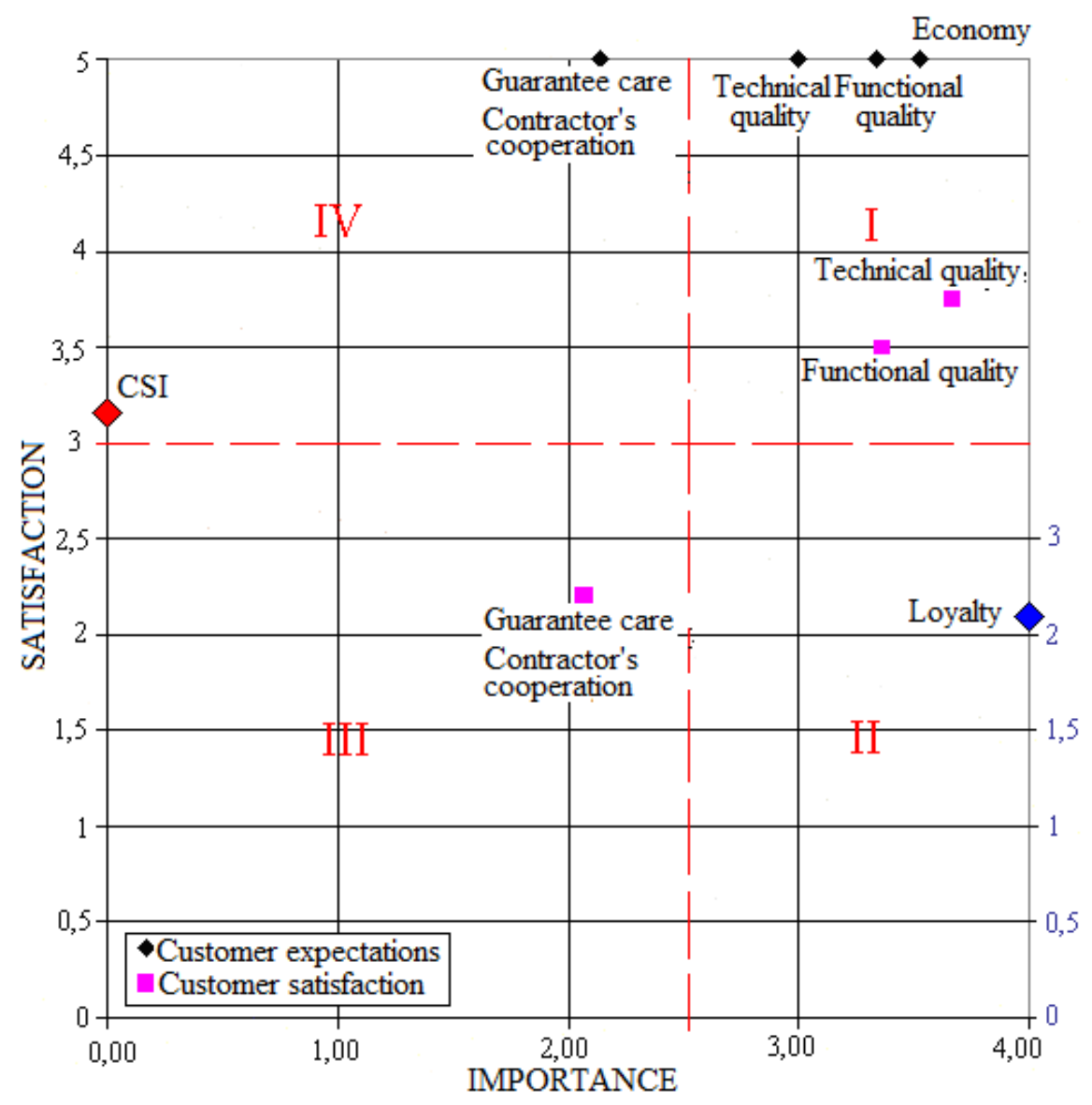

Fig. 7. Customer satisfaction matrix. Source: Own study.

The diagram shows the total customer satisfaction (CSI rate 3.15 points) determined during the research covering the assessment of new apartment buildings of several different designs, customer satisfaction with dwellings, and the quality of housing from the customers' perspective. The diagram suggests that cooperation between builders/principals and customers is the area that needs the most improvement. The technical and functional quality, from the customers' perspective, is average, because new housing designs of better quality offset designs that lead to dwellings with abundant defects and poor satisfaction of customers' needs. Companies involved in residential construction would benefit from separate assessments of their customers' satisfaction. The right axis of the diagram shows the general loyalty of customers (2.08 points) determined considering their desire to move, irrespective of their possibilities to do so, their readiness to recommend the dwelling to other customers, and loyalty as assessed by the customers themselves. Customer loyalty determined during the research is at $69 \%$, and 
thus only average. Such a level of customer satisfaction can be considered as an opportunity for companies involved in residential construction. However, one must keep in mind that customers with average satisfaction differ greatly from those who are completely satisfied, thus the average customer satisfaction-not gratification with exceeded expectations-determined during our research does not necessarily guarantee customer loyalty in the future, particularly in the housing sector. Moreover, customer satisfaction is not constant and changes with new experiences. Continuous surveys of customer satisfaction, as well as the monitoring of changes in the customers' needs and expectations are, therefore, essential.

\section{Conclusions}

1. Customer satisfaction with dwellings is subjective and depends on their social background, habits, circumstances, experiences, expectations and needs. Lithuanian construction companies should use the customer feedback model, which provides information about customer satisfaction, leads to better decisions and helps to improve the quality of housing-related services and products.

2. The survey of customer satisfaction with new apartment houses via an online questionnaire showed that economic motives, as well as the functional and technical properties of dwellings are the most important when choosing a dwelling.

3. At 3.15 points, the total Customer Satisfaction Index (CSI) shows that the customer satisfaction with dwellings in new apartment buildings is average $(63 \%)$. The technical and functional quality is average, because new housing designs of better quality offset those of lower quality with defects. The technical index $\left(\mathrm{CSI}_{\mathrm{T}}\right.$ of 3.75 points) shows the satisfaction of needs to be at $75 \%$, while the functional index $\left(\mathrm{CSI}_{\mathrm{F}}\right.$ of 3.49 points) - at $69.6 \%$. The index of the warranty services and the builders' prompt response to complaints $\left(\mathrm{CSI}_{\mathrm{G}}\right.$ of 2.2 points) is the lowest, below that of average satisfaction (satisfaction of needs at $44 \%$ ), thus customers can be said to be completely discontent.

4. The main defects in new apartments are: smaller and larger cracks, condensation, misting, poor sound and thermal insulation, poor precipitation drainage and ventilation systems, improper façade finishing, bad roofing and balconies, defects in common areas, and moisture and mold. The main indicators of poor functional quality are: the lack of places to park cars, too close proximity of neighboring buildings, the lack of green areas, poor courtyard infrastructure, poor accessibility, unfinished construction nearby, and poor layouts of dwellings.

5. Considering their experiences with builders/principals who are not keen to handle issues eliminating defects and reimbursing loss, and try to evade liability (buildings not certified for occupancy, bankruptcies, blame placed on contractors and subcontractors), customers are slow to defend their rights. The dominating opinion is that the defects are minor if the dwelling is suitable for living; dwellings are also not easy to change due to financial circumstances.

6. Considering the desire to change dwellings and readiness to recommend them to other customers, customer loyalty stands at 69.33\%; customer loyalty is, hence, average. Builders should make attempts to better satisfy customer needs; loyalty would then improve, and the companies would have more opportunities for future projects.

7. The Lithuanian real estate market is undergoing a process of essential changes; customers are gaining more experience and knowledge, while the market has a large supply of residential housing; thus, in the near future, housing projects can be expected to be of top quality and wellsuited to customers' needs.

\section{References}

ANDERSON E. W., FORNELl C., Rust, R.T., 2001, Customer Satisfaction, Productivity and Profitability: Differences Between Goods and Service, Marketing Science 16 (2), pp. 129-145.

BAGDONIENĖ L., HoPENIENĖ R., 2004, Paslaugu marketingas ir vadyba (Service Marketing and Managementin Lithuanian). Kaunas: Technologija. p. 468.

BARRETT P., 2000, Systems and Relationships for Construction Quality. International Journal of Quality \& Reliability Management 17 (4/5), pp. 377-392.

ČIUladA M., 2008. Nuosavas būstas - bütinybe (Own Housing - a Necessity) (in Lithuanian). Statyba ir architektūra 6, pp. 73.

DAUNORIENE A., DAUNORAS A., 2006, Suinteresuotuju šaliu poreikiu tenkinimas statybiniu paslaugu rinkoje (Satisfaction of Stakeholders' Needs in the Market of Building Services) (in Lithuanian). p. 4. [Accessed 2015-04- 
20].http:/ / www.elibrary.lt/resursai/Mokslai/Kolegijos/Kolpingo_kolegija/konferencija2006/05. pdf.

DIKAVIČIUS V., STOŠKUS, S., 2003, Visuotine kokybès vadyba (Total Quality Management) (in Lithuanian). Kaunas: Technologija. p. 128.

ENCIUS R., 2008, Variklis kokybei gerinti (Engine to Improve Quality) (in Lithuanian). Statyba ir architektūra, 10, pp. 14-18.

FORSYTHE P., 2008, Modelling Customer Perceived Service Quality in HousingCconstruction. Engineering, Construction and Architectural Management, 15 (5), pp. 485-496.

GYVENAMOJO NEKILNOJAMOJO TURTO RINKOS KOMENTARAS, 2015, (Residential Real Estate Market Commentary) (in Lithuanian) [Accessed 2015-04-21]. Internet address: http://www.oberhaus.lt/files/OH_Gyvenamasis_2009_IV_ketv.pdf.

Haupt T. C., Whiteman D. E., 2004, Inhibiting Factors of Implementing Total Quality Management on Construction Sites. Total Quality Management Magazine, 16(3), pp. 166-173.

Holt R., Rowe, D., 2000, Total Quality, Public Management and Critical Leadership in Civil Construction Projects. International Journal of Quality \& Reliability Management, 17 (4/5), pp. 541-553.

HSIEH H.Y., FORSTER J., 2006, Residential Construction Quality and Production Levels in Taiwan. Engineering, Construction and Architectural Management, 13(5), pp. 502-520.

NURUL AFIDA ISNAINI JANIPHA, FARIDAH ISMAIL, 2013, Conceptualisation of Quality Issues in Malaysian Construction Environment. Quality of Life in the Built and Natural Environment. Procedia - Social and Behavioral Sciences, 101 ( 2013 ), pp. 53 - 61.

JiboYE A. D., 2009, Evaluating Tenants' Satisfaction with Public Housing in Lagos, Nigeria. Urbanistika ir architektūra, 33(4), pp. 239-247.

KÄRNÄ S., 2004, Analysing Customer Satisfaction and Quality in Construction - the Case of Public and Private Customers. Nordic Journal of Surveying and Real Estate Research, 2, pp. 67-80.

KÄRNÄ, S., JUNNONEN J.M., KANKAINEN J., 2004, Customer Satisfaction in Construction, 12 p. [Accessed 2015-04-25]. Internet address: http://www.iglc2004.dk/_root/media/13072_059-karna-junnonenkankainen-final.pdf

KÄRnÄ, S., JunnONEn J.M., SORVAlA V.M., 2009, Classifying and Clustering Construction Projects by Customer Satisfaction. Facilities Journal, 27 (9/10): 17 p.

KÄRNÄ, S., JUNNONEN J.M., SORVALA V.M., 2009a, Modelling Structure of Customer Satisfaction with Construction. Journal of Facilities Management, 7(2), pp. 111-127.

Kondo Y., 2001, Customer Satisfaction: How Can I Measure it?, Total Quality Management \& Business Excellence, $12(7 / 8)$, pp. 867-872.

KOSKELA H., 2002, Customer Satisfaction and Loyalty in After Sales Service: a research report. Espoo [Accessed 2015-04-23]. Internet address: http:/ /lib.tkk.fi/Diss/2002/isbn9512258994/ isbn9512258994.pdf.

KOTLER P., 2003, Marketing Management, 11 th Edition, p. 706.

KUČINSKAITĖ J., 2007, Kas dengia statybininku mafija (Who Covers the Builders' Mafia) (in Lithuanian). [Accessed 2015-04-23]. Internet address: http:/ / www.mediabv.lt/res_zinpr_det.php?id=16885.

KujALA S., 2002, A Practical Approach to User Involvement for Gathering user Needs and Requirements. Espoo [Accessed 2015-04-22]. Internet address: http:/ /lib.tkk.fi/Diss/2002/isbn9512259001/ isbn9512259001.pdf.

Kujala S., KaupPINEN M., 2001, Bridging the Gap Between User Needs and User Requirement. Proceedings of the Panhellenic Conference with International Participation in Human-Computer Interection. Typorama publications, pp. 45-50.

LePKOVA N., ŽüKAITĖ G., 2012, Study on Customer Satisfaction with Facilities Management Services in Lithuania. Slovak journal of civil engineering. Bratislava: Versita. ISSN 1210-3896. Vol. 20, No. 4 (2012), pp.1-16.

LST ISO 9001, 2008, Kokybès vadybos sistemos. Reikalavimai (Quality Management System. Requirements) (in Lithuanian). Vilnius: Lietuvos standartizacijos departamentas, p. 30.

MATERIALINĖS INVESTICIJOS IR STATYBA (Capital Investment and Construction) (in Lithuanian). Statistikos Departamento statistikos biuletenis, 2010, Vilnius, p. 38.

MiNiUS A., SūDŽIUS V., 2008, Kas pašalins statybų broka (Who will Remove Construction Defects) (in Lithuanian) [Accessed 2015-04-10]. Internet address: http:/ / www.vartotojulyga.lt/lt/news/ detail.php?ID=18635. 
OlaDAPO A., 2006, A Study of Tenant's Maintenance Awareness, Responsibility and Satisfaction in Housing in Nigeria. International Journal of Strategic Property Management, 10, pp. 217-231.

PeKKANEN J., 2005, Threats and Opportunities with Customer Relationships in Construction Projects: a Research Report. Espoo [Accessed 2015-04-25]. Internet address: http://lib.tkk.fi/Diss/2005/ isbn9512279339/.

PHENG S.L., 2001, Quantifying the Relationships Between Buildability, Structural Quality and Productivity in Construction. Structural Survey 19 (2), pp. 106-112.

REAL ESTATE MARKET REPORT 2010, Baltic States Capitals [Accessed 2015-04-21]. Internet address: http://www.oberhaus.lt/files/OberHaus\%20Real\%20Estate\%20Annual\%20Market\%20Report\%20 2010\%20Baltic\%20Capitals.pdf

RONDEAU E.P., BROWN, R.K., LAPIDES P.D., 2006, Facility Management. p. 573.

Soetanto R., Proverbs D.G., Holt G.D., 2001, Achieving Quality Construction Projects Based on Harmonious Working Relationships. Clients' and Architects' Perceptions of Contractor Performance. International Journal of Quality \& Reliability Management, 18 (5), pp. 528-548.

StATISTIKOS DEPARTAMENTO METINIAI PASTATỤ STATYBOS DUOMENYS (Department of Statistics, Annual Building Construction Data) (in Lithuianian) [Accessed 2015-04-20], Internet address: http://www.stat.gov.lt/lt/pages/view/?id=2441.

StaTiSTics LithuANia, 2015, Statistical Yearbook of Lithuania. Housing, Vilnius, p. 704, Internet access: http:/ / osp.stat.gov.lt/services-portlet/pub-edition-file?id=21218.

THE AMERICAN CUSTOMER SATISFACTION INDEX [Accessed 2015-04-10], Internet address: http:/ / www.theacsi.org/index.php?option=com_content\&task=view\&id=49\&Itemid=28.

ThijS N., StAes P., 2008, European Primer on Customer Satisfaction Management, European Quality Conference, Paris, p. 107.

TORBICA Ž.M., STROH R.C., 2001, Customer Satisfaction in Home Building. Journal of Construction Engineering and Management, 127(1), pp. 82-86.

URbANAVIČIENĖ V., KAKLAUSKAS A., ZAVADSKAS E.K., 2009, The Conceptual Models of Construction and Rreal Estate Negotiation. International Journal of Strategic Property Management, 13 (1), pp. 53-70.

VARTOTOJU TEISIŲ APSAUGA ENERGETIKOS IR KOMUNALINIŲ PASLAUGŲ SRITYJE, 2009, (Protection of Consumers' Rights in Energy and Utility Services) (in Lithuanian). Lietuvos vartotoju asociacija 2009 [Accessed 2015-04-27], Internet address: http://www.vartotojuteises.lt/projektai/ vartotoju_teisiu_apsauga_energetikos_ir_komunaliniu_paslaugu_srityje.

VIEŠU̦JU PASLAUGŲ VARTOTOJŲ PASITENKINIMO INDEKSO APSKAIČIAVIMO METODIKA,2010, (Calculation Methodology of Public Service Customer Satisfaction Index) (in Lithuanian). Lietuvos Respublikos vidaus reikalu ministerija. 70 p. [Accessed 2016-01-10], Internet address: http:/ / www3.lrs.lt/pls/inter3/dokpaieska.showdoc_1?p_id=348227\&p_query=\&p_tr2=2.

ŹRÓBEK S., TROJANEK M., ŹRÓBEK-SOKOLNIK A., TROJANEK R., 2015, The Influence of Environmental Factors on Property Buyers' Choice of Residential Location in Poland. Journal of International Studies Vol. 7, No 3, pp. 163-173. 